Primeros registros de Balaenoptera edeni (Cetartiodactyla:

Balaenopteridae) en la costa de Oaxaca, México

\title{
First records of Balaenoptera edeni (Cetartiodactyla: Balaenopteridae) in the coast of Oaxaca, Mexico
}

\author{
Francisco Villegas-Zurita ${ }^{1 *}$, Fátima Castillejos-Moguel${ }^{2}$, Susana Cabrera-Núñez ${ }^{2}$ y Raúl Fernando Ramírez-Barrragán ${ }^{2}$ \\ ${ }^{* 1}$ Instituto de Ecología, Universidad del Mar. Ciudad Universitaria, Puerto Ángel, Oaxaca. 70902. México. E-mail: fvillegas@angel.umar.mx. \\ ${ }^{2}$ Mamíferos Marinos de Oaxaca Biodiversidad y Conservación A. C. Carretera a Zipolite km 1, 70902. Puerto Ángel, Oaxaca, México. \\ E-mail:mmobidic@hotmail.com \\ ${ }^{*}$ Corresponding author
}

To date, few studies have focused on the Bryde's whale, Balaenoptera edeni, one of the eigth species comprising the family Balaenopteridae. This species can be distinguished from other rorquals by the presence of three parallel longitudinal ridges on top of the rostrum, whereas other rorquals possess only one. The potential distribution of this species in the Mexican Pacific is thought to extend south from $26^{\circ} \mathrm{N}$, along the coast of Mexico from Baja California to the border with Guatemala. Our knowledge about this species in the Mexican South Pacific is limited, particularly off the coast of Oaxaca where no previous sightings have been reported. The sightings were recorded during oceanic trips to monitor humpback whale (Megaptera novaeangliae) migrations off the central coast of Oaxaca, Mexico, between December 2011 and January 2012. The observation platforms were $6 \mathrm{~m}$ fiberglass boats with a $60 \mathrm{hp}$ outboard engine. The geographical coordinates were registered with a handheld GPS; also recorded were sea surface temperature and the behavior of rorqual specimens. The initial species identification was based on the presence of three parallel longitudinal ridges on the head, and was subsequently corroborated by comparing the photographs and video taken during the sightings with field guides. Four separate rorqual sightings were documented between 1.3 and $7.1 \mathrm{~km}$ from the coast of Estacahuite, Zipolite, and Ventanilla, Oaxaca, Mexico. Two sightings involved groups with calves; during one sighting, three killer whales, Orcinus orca, were also observed, although neither predatory behavior nor other interaction occurred. The behaviors observed included breaches by calves, surface activity, and slow and erratic movements with sudden changes of direction in response to the presence of the research boat. During surface exhalations, one individual produced vocalizations that were audible at the surface. The presence of $B$. edeni off the central coast of Oaxaca, Mexico, may be associated with the oceanographic characteristics and high productivity of the Gulf of Tehuantepec. All behaviors observed during the sightings were typical of the species, including evasive maneuvers and sudden changes of direction with respect to the boat. The fortuitous recording of audible vocalizations clearly recognizable from the research boat during surface exhalations is remarkable. These sightings are the first reports of $B$. edeni for the state of Oaxaca and the Mexican South Pacific. Thus, there is a clear need to increase intensive, long-term monitoring efforts in order to better understand the ecological implications and other aspects related to the presence of the Bryde's whale and other marine mammals in the region. Future research should focus on assessing the spatial and temporal occurrence of $B$. edeni in this region.

Key words: Bryde's whale; central coast of Oaxaca; distribution; mexican south Pacific; sightings.

El rorcual tropical Balaenoptera edeni, es probablemente la especie menos estudiada de las ocho que comprende la familia Balaenopteridae. Puede identificarse por la presencia de tres quillas paralelas situadas en la región dorsal de la boca, a diferencia de otros rorcuales que poseen solo una. En el Pacífico mexicano su distribución potencial puede extenderse hacia el sur a los $26^{\circ} \mathrm{N}$, desde Baja California, a lo largo de la costa continental de México hasta la frontera con Guatemala. En la región del Pacífico Sur mexicano el conocimiento sobre la especie es limitado, particularmente en la costa de Oaxaca se carecía de registros. Los avistamientos se registraron durante navegaciones para el monitoreo de la migración de ballena jorobada (Megaptera novaeangliae) en la Costa Central de Oaxaca, entre diciembre de 2011 y enero de 2012. Las observaciones fueron hechas desde embarcaciones de fibra de vidrio de seis $m$ de eslora y motor fuera de borda de $60 \mathrm{hp}$. Se registraron las coordenadas con GPS de mano, temperatura superficial del mar y comportamientos. La identificación de la especie fue corroborada por la presencia de las tres quillas paralelas en el rostro, empleando el material fotográfico y de video tomado durante los avistamientos y consultado en guías de campo. Se documentaron cuatro avistamientos entre 1.3 y $7.1 \mathrm{~km}$ de la costa, frente a las costas de Estacahuite, Zipolite y Ventanilla. En dos avistamientos se observaron grupos con crías y en uno se observó el encuentro con un grupo de tres orcas Orcinus 
orca sin mostrar interacción ni conducta depredatoria hacia los rorcuales. Los comportamientos registrados en la superficie fueron saltos de cría, actividad en superficie, desplazamiento lento y errático con cambios repentinos para evadir la embarcación. Además, en un individuo se documentó la emisión de sonidos audibles en superficie durante los soplos. La presencia de B. edeni en la zona costera de Oaxaca, puede estar asociada a las características oceanográficas y a la alta productividad del Golfo de Tehuantepec. Los comportamientos registrados fueron característicos de la especie, ya que en todos los avistamientos se mostraron evasivas hacia la embarcación con cambios repentinos en su dirección. Lo relevante en este reporte fue el registro fortuito de vocalizaciones audibles durante las respiraciones en superficie, las cuales se escucharon claramente desde la embarcación. La importancia de estos registros radica en que son los primeros reportes de $B$. edeni para el estado de Oaxaca y la región del Pacífico Sur mexicano. Lo anterior, hace evidente la necesidad de incrementar los esfuerzos de monitoreo de forma intensiva y de largo plazo, tendientes a conocer aspectos ecológicos de los mamíferos marinos y en especial de la especie, su posible presencia a lo largo del año en las costas de Oaxaca y los factores que determinan su ocurrencia espacial y temporal en esta región.

(c) 2016 Asociación Mexicana de Mastozoología, www.mastozoologiamexicana.org

\section{Introduction}

The Bryde's whale, Balaenoptera edeni (Anderson, 1879), is probably the least studied baleen whale; it is listed in the Data Deficient (DD) risk category of the International Union for the Conservation of Nature's Red List (IUCN 2016), and is classified as a species subject to special protection (Pr) in the Mexican Official Standard NOM-059-SEMARNAT-2010 (DOF 2010). It can be identified by the presence of three parallel longitudinal ridges on top of the rostrum, unlike other rorquals, which possess a single ridge (Jefferson et al. 1993; Carwardine 2002). The prominence of these ridges is variable and difficult to observe from a research boat at sea; for this reason, this species was misidentified as either the sei whale (B. borealis; Jefferson et al. 1993) or other species such as the fin whale (B. physalus) and the antarctic minke whale or southern minke whale (B. bonaerensis; Niño-Torres et al. 2011). It has a relatively small, elongated and slim body that measures up to 14.6 $\mathrm{m}$ (Reeves et al. 2002). The pectoral fins are relatively short and with a pointed tip, and the dorsal fin is prominent and falcate, located at about two thirds of the total body length (Carwardine 2002; Reeves et al. 2002). The body coloration pattern is variable, being black-bluish dorsally and white or yellowish ventrally (Guerrero-Ruíz et al. 2006; Niño-Torres et al. 2011).

The Bryde's whale has a pan-tropical distribution between $40^{\circ} \mathrm{N}$ and $40^{\circ} \mathrm{S}$, or delimited by the $20^{\circ} \mathrm{C}$ isotherm, and can be seen near the coast and in areas of high productivity (Carwardine 2002; Guerrero-Ruíz et al. 2006). In the North Pacific, it is found from California to Central America, and in the Mexican Pacific its potential distribution may extend south to $26^{\circ} \mathrm{N}$, from Baja California along the continental coast of Mexico to the border with Guatemala (Urbán and Flores 1996; Urbán and Guerrero-Ruíz 2008). Some authors have suggested the existence of two populations in the Gulf of California: a resident one, of which calves have been observed throughout the year, and another one associated with the Eastern Tropical Pacific population (Tershy et al. 1990; Niño-Torres et al. 2011). In the Mexican South Pacific, the knowledge about the species is scarce, particularly for the coast of Oaxaca, where the presence of this species has not been previously recorded.

During oceanic trips for monitoring the migration of the humpback whale (Megaptera novaeangliae) in the Central Coast of Oaxaca, conducted by Mamíferos Marinos de Oaxaca Biodiversidad y Conservación Asociación Civil (MMOBiDiC AC) and Universidad del Mar, four sightings of $B$. edeni were recorded between December 2011 and January 2012. The observation platforms used were $6 \mathrm{~m}$ fiberglass boats with a $60 \mathrm{hp}$ outboard engine. B. edeni was first identified based on the presence of the three ridges on top of the rostrum using the photographs and videos taken during the sightings, and comparing the morphological characteristics with the descriptions by Reeves et al. (2002).

The first two sightings occurred on 10 December 2011 (Figure 1), the first record being at 12:01 hours, $7.1 \mathrm{~km}$ off Estacahuite bay $\left(15^{\circ} 36^{\prime} 43.4^{\prime \prime} \mathrm{N},-96^{\circ} 26^{\prime} 28.8^{\prime \prime} \mathrm{W}\right)$, where a single specimen was 
observed moving slowly to the southeast and breaching on two occasions. Later, a mother and a calf were sighted at 13:07 h, $1.3 \mathrm{~km}$ off Estacahuite $\left(15^{\circ} 39^{\prime} 27.06^{\prime \prime} \mathrm{N},-96^{\circ} 26^{\prime} 47.7^{\prime \prime} \mathrm{W}\right)$, also moving slowly to the southeast. In both sightings, the local sea surface temperature was $26^{\circ} \mathrm{C}$.

On 27 January 2012, two additional sightings were recorded. The first occurred at 8:21, 4.4 $\mathrm{km}$ from Roca Blanca island, in front of Zipolite beach (Figure 1). Five individuals were observed, including a calf $\left(15^{\circ} 36^{\prime} 54.1^{\prime \prime} \mathrm{N},-96^{\circ} 31^{\prime} 52.0^{\prime \prime} \mathrm{W}\right)$; sea surface temperature was $26^{\circ} \mathrm{C}$. The individuals displayed an active surface behavior along with erratic movements to the northwest, evading the observation platform with sudden changes of direction. In this occasion, three individuals of Orcinus orca (a calf and two females: an adult and a juvenile) were observed moving in the opposite direction to the group of Bryde's whales and five meters apart from them. Although there are reports of killer whales (Orcinus orca) hunting Bryde's whales in the Gulf of California (Silber et al. 1990), neither interactions nor predatory behaviors were noticed during the sighting reported here, as both groups moved away from one another in their respective directions. The second sighting was of a mother with a calf, at 9:56, $4.7 \mathrm{~km}$ off Ventanilla beach ( $15^{\circ} 37^{\prime} 57.4^{\prime \prime} \mathrm{N},-96^{\circ} 36^{\prime}$ $35.6^{\prime \prime} \mathrm{W}$ ), moving slowly with erratic movements to the southeast. Both individuals displayed an active surface behavior and evaded the boat; the calf performed two full-body breaches belly up (one of which was partially recorded on video). During the sighting, the emission of vocalizations or sounds by the mother were recorded on video on three occasions, after surface breathing, which were clearly audible from the boat and lasted approximately one second.

It has been suggested that the occurrence and displacement of this rorqual are influenced by prey availability, which in turn is affected by environmental variability; in the Gulf of California, a larger number of rorquals have been observed in La Niña cold conditions that facilitate the migration of sardines into the Gulf (Salvadeo et al. 2011). Its presence in the coastal area of Oaxaca may be associated with the oceanographic characteristics and high productivity that prevail in the Gulf of Tehuantepec, which define this region as a center of high biological activity (Ortega-García et al. 2000). In addition, the anchovy, a prey consumed by the Bryde's whale, (Guerrero-Ruíz et al. 2006), has been reported as one of the most abundant species, both in number and in weight, in the Gulf of Tehuantepec at the beginning of the dry season (winter-spring), when Tehuano winds give rise to upwelling events and a significant drop of sea surface temperature (Ayala-Duval et al. 1988).

On the other hand, the behaviors recorded were typical of the species, since in all sightings rorquals evaded the boat with sudden changes of direction. A remarkable fact was the fortuitous record of audible vocalizations during surface breaths, which were clearly heard from the boat.

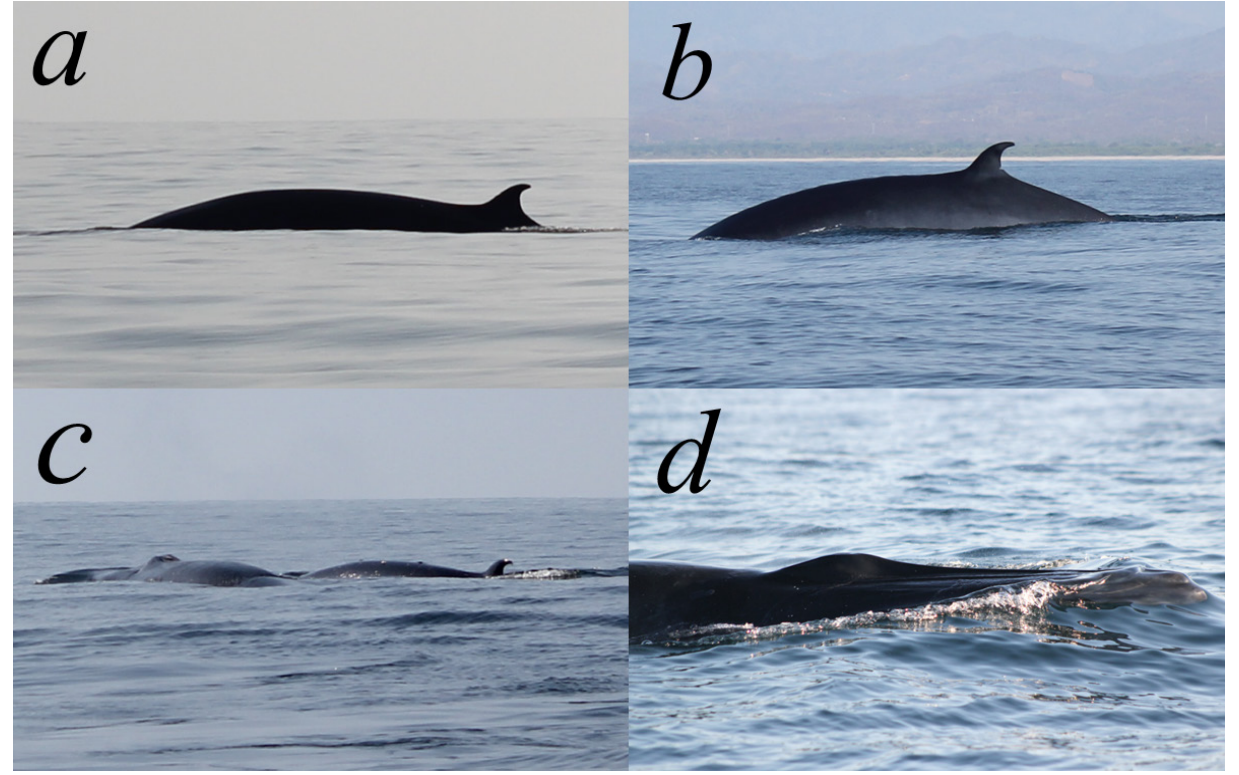

Figure 1. Balaenoptera edeni individuals recorded between December 2011 and January 2012 in the central coast of Oaxaca. $a$ and $b$ show adult specimens; $c$, a mother and a calf, and $d$, the parallel lateral ridges on top of the rostrum that is characteristic of the species. 


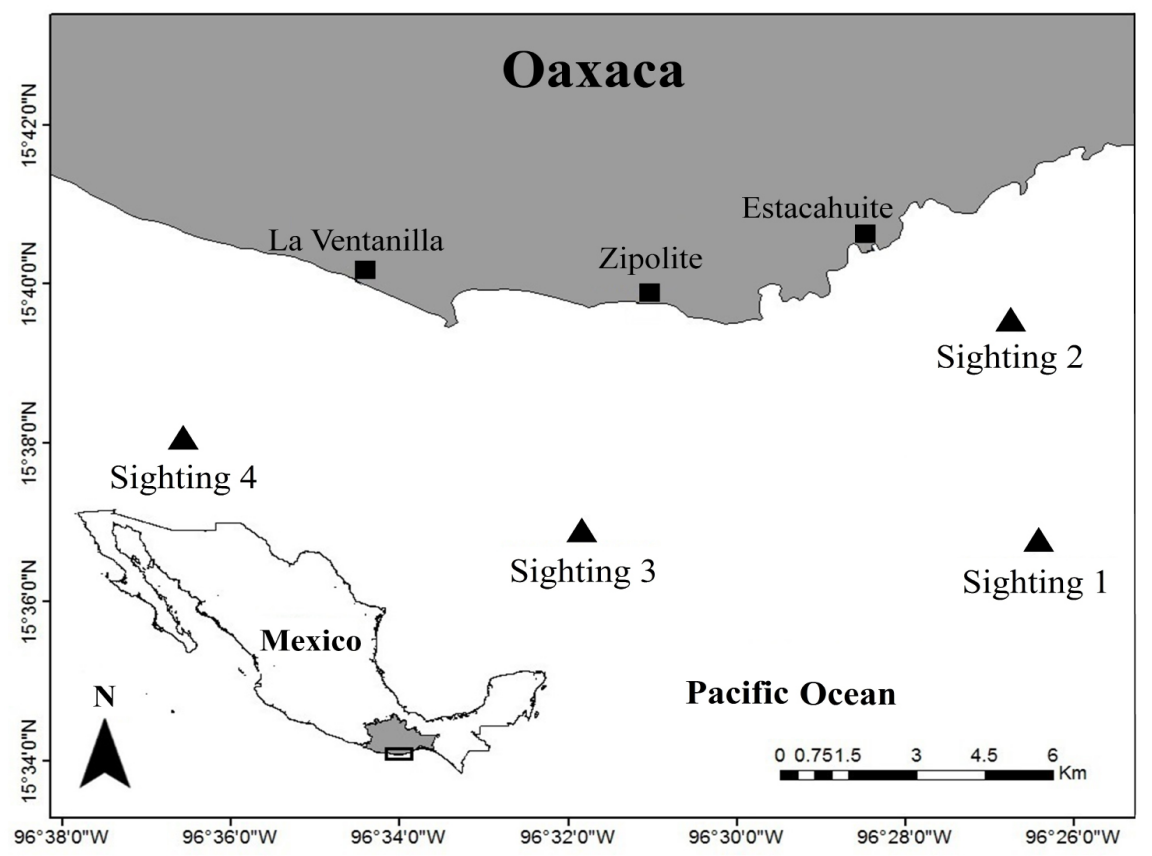

Figure 2. Distribution of the sightings of Balaenoptera edeni in the central coast of Oaxaca between December 2011 and January 2012.

These records are relevant for being the first reports of $B$. edeni for the state of Oaxaca, particularly since studies on the Bryde's whale in the Mexican Pacific are scarce and the effort has focused on very specific areas of the north and west zones. These findings point to the need to conduct intensive long-term monitoring in the Mexican South Pacific, aimed at investigating ecological aspects of marine mammals, in particular focusing on the Bryde's whale, its presence throughout the year in the Pacific coast of Oaxaca, and the factors that determine its spatial and temporal occurrence in this region.

The authors would like to thank UMAR for financing the project 2IE1207, to MMOBiDiC A. C., and ALIAM S. A. de C. V. for their contribution to financing the ocean trips of the Programa Permanente de Monitoreo de Mamíferos Marinos de la Costa Central de Oaxaca. Thanks also to the volunteers who participated during the ocean trips of the program. Finally, to the anonymous reviewers who provided valuable comments to improve the manuscript. This manuscript was translated by Maria Elena Sánchez Salazar with support of THERYA through a CONACYT grant.

\section{Literature Cited}

Ayala-Duval, E., M. C. Maldonado-Monroy, J. A. Becerril-Martínez, D. T. Garcia-Tamayo, C. Juarez-Ortiz, J. Blas-Cabrera, V. Barrios-Orozco, J. A. Hueta-Gonzalez, and A. Almaraz-Gomez. 1988. Distribución de algunos componentes del ictioplancton y su relación con la biomasa zooplanctónica. Pp. 93102, in El Golfo de Tehuantepec: el ecosistema y sus recursos (Tapia-Garcia M., ed.). Universidad Autónoma Metropolitana-Iztapalapa. Ciudad de México, México.

Carwardine, N. 2002. Whales, dolphins and porpoises. Second editon, Dorling Kindersley. New York, U. S. A. DOF. 2010. NOM-059-SEMARNAT-2010: Protección ambiental-Especies nativas de México de flora y fauna silvestre-Categorías de riesgo y especificaciones para su inclusión, exclusión o cambio Lista de especies en riesgo. Diario Oficial de la federación 30 de diciembre de 2010.

Guerrero-Ruíz, M., J. Urbán-Ramírez, and L. Rojas. 2006. Las ballenas del golfo de California. Instituto Nacional de Ecología (INE). Secretaría de Medio Ambiente y Recursos Naturales (SEMARNAT). Ciudad de México, México. 
IUCN. 2016. Balaenoptera edeni. The International Union for Conservation of Nature and Natural Resources. Red list of threatened species. Consultado el 14 de marzo de 2013 en: http://www. iucnredlist.org/details/2476/0

Jefferson, T. A., S. Leatherwood, and M. A. Webber. 1993. FaO species identification guide. Marine mammals of the world. Rome, Italy.

Niño-Torres, C. A., J. URbán-Ramírez, and O. Vidal. 2011. Mamíferos Marinos del Golfo de California: Guía ilustrada. Publicación especial No. 2, Alianza WWF México-Telcel. Ciudad de México, México

Ortega-García, S., J. A. Trigeros-Salmerón, R. Rodríguez-Sánchez, S. Lluch-Cota, and H. Villalobos. 2000. El Golfo de Tehuantepec como un centro de Actividad Biológica y su importancia en las pesquerías. Pp. 335-356 in, BAC: Centro de Actividades Biológicas del Pacífico Mexicano (Lluch-Belda D., J. Elorduy-Garay S. Lluch-Cota y G. Ponce-Díaz, eds.) CIBNOR, CICIMAR, CONACYT. La Paz, México.

Reeves, R. R., B. S. Steward, P. J. Clapham, and J. A. Powell. 2002. Guide to Marine Mammals of the World. Alfred A. Knopf. New York, U. S. A.

Salvadeo, C. J., S. Flores-Ramírez, A. Gómez-Gallardo, C. Macleod, D. Lluch-Belda, S. Jaume-Schinkel, and R. J. URBán. 2011. El rorcual de Bryde (Balaenoptera edeni) en el suroeste del Golfo de California: Su relación con la variabilidad de ENOS y disponibilidad de presas. Ciencias Marinas 37:215-225.

Silber, G., M. W. Newcomer, and H. Pérez. 1990. Killer whales (Orcinus orca) attack and kill a Bryde's whale (Balaenoptera edeni). Canadian Journal of Zoology 68:1603-1606

Tershy, B., R. Breese, and C. S. Strong. 1990. Abundance, seasonal distribution and population composition of balaenopterid whales in the Canal de Ballenas, Gulf of California, Mexico. Reports of the International Whaling Commission. Species 12:369-375.

Urbán, R., J., And M. Guerrero-Ruíz. 2008. Ficha técnica de Balaenoptera edeni. In Conocimiento biológico de las especies de mamíferos marinos, incluidas en la Norma Oficial Mexicana 059-SEMARNAT-2001 (Urbán R J, ed.). Universidad Autónoma de Baja California Sur. Bases de datos SNIB-CONABIO. Proyecto No. CK009. La Paz, México.

URBÁn, R., J., AND S. R. Flores. 1996. A note on Bryde's whales (Balaenoptera edeni) in the Gulf of California, Mexico. Reports of the International Whaling Comission 46:453-457.

Submitted: April 18, 2016

Reviewed: August 15, 2016

Accepted: August 26, 2016

Associated editor: Juan Pablo Gallo 
BRYDE'S WHALE IN OAXACA

504 THERYA Vol.7 (3): 499-503 